\title{
Enterotoxin production by Salmonella typhimurium strains of different virulence
}

\author{
T. S. WALLIS, W. G. STARKEY, J. STEPHEN, S. J. HADDON*, M. P. OSBORNE* and \\ D. C. A. CANDY†
}

Departments of Microbiology and *Physiology, University of Birmingham, P.O. Box 363, Birmingham B15 2TT, and tInstitute of Child Health, Francis Road, Birmingham B16 8ET

\begin{abstract}
Summary. Six strains of Salmonella typhimurium (TML, W118, LT7, SL1027, M206 and Thax-1) of known virulence and ability to induce fluid secretion when inoculated into the rabbit ileum were examined for enterotoxin production. Enterotoxic activity, assayed in the rabbit ileal-loop test, was detected in polymyxin-B extracts from all strains (with the possible exception of Thax-1) cultured for $6 \mathrm{~h}$ in casamino acid-yeast extract medium. The extracts were inactive in tissue-culture assays with $\mathrm{CHO}, \mathrm{Y}-1$ adrenal and Vero cells, and in the infant mouse assay for enterotoxin. There was no correlation between enterotoxigenicity in vitro and the ability of whole organisms to induce fluid secretion in vivo. The significance of these results in relation to salmonellosis is discussed.
\end{abstract}

\section{Introduction}

The production of diarrhoea by non-typhoid salmonellae has been investigated for 20 years. Key contributions of early workers have recently been reviewed (Stephen et al., 1985). It appears that salmonella-induced diarrhoea is a complex phenomenon that may involve several mechanisms.

Giannella et al. (1973) showed that Salmonella typhimurium strains could be divided into three biotypes according to their behaviour in ligated rabbit ileal loops. They reported that two strains (TML and W118) isolated from human clinical cases invaded the mucosa of rabbit ileal loops, induced fluid secretion, then spread to bloodstream, liver and spleen. Strain M206 invaded the mucosa of rabbit ileal loops and was cultured from blood, liver or spleen only occasionally, whereas strain Thax-1 was non-invasive; strain M206 induced fluid secretion but strain Thax-1 did not. Strains SL1027 and LT7 were invasive (i.e., they could be isolated from internal organs) but caused no fluid accumulation in rabbit ileal loops. Orogastric challenge of rhesus monkeys with strains TML and W118 induced diarrhoea; strain SL1027 induced diarrhoea in only one of 13 monkeys challenged, whereas strain M206 never induced diarrhoea. Strains Thax1 and LT7 were not tested. Culture supernates of all strains were tested for enterotoxic activity in the rabbit ileal-loop test (RILT) and gave negative results (Giannella et al., 1973).

The demonstration that enterotoxins play an

Received 18 Mar. 1985; accepted 15 Apr. 1985.

Correspondence should be sent to Dr J. Stephen. important role in diarrhoeal diseases caused by Vibrio cholerae and Escherichia coli has re-awakened interest in the possible role of enterotoxins in salmonellosis. Enterotoxic activities of non-typhoid salmonellae have been reported by several groups of workers who have used various cell and animal tests. The properties of the enterotoxic entity are said to resemble those of cholera toxin (CT) (Sandefur and Peterson, 1977; Finkelstein et al., 1983), E. coli heat-stable toxin (ST) (Koupal and Deibel, 1975; Jiwa and Mansson, 1983), shiga toxin (ShiT) (O'Brien et al., 1982; Koo et al., 1984) and even a hybrid CT-ShiT (Kétyi et al., 1979). Extracts of strain W118 were tested for ShiT by Dr A. D. O'Brien (O'Brien et al., 1982) and again at our request and contained $20 \mathrm{CD}_{50}$ of ShiT/mg of protein; comparable extracts from Shigella dysenteriae type 1 contained $3 \times 10^{5} \mathrm{CD}_{50}$ of ShiT/mg of protein ( $1 \mathrm{CD}_{50}$ kills $50 \%$ of tissue-culture cells exposed). Dr J. B. Kaper (Center for Vaccine Development, University of Maryland, Baltimore USA) has also kindly examined all six strains for possession of genes which will hybridize with probes for CT and ST genes and failed to find any.

The role of salmonella enterotoxin (of whatever class or subclass) in the causation of disease is far from clear. In most cases, enterotoxic activity has been found in bacterial extracts and not in culture supernates. Also the results of cell tests have little or no predictive value for other tests (Jiwa, 1981). In this paper we describe the production of enterotoxin(s) by $S$. typhimurium grown in vitro. Strains used were selected because of their established behaviour patterns in man, monkeys and rabbit ileal loops 
(Giannella et al., 1973). The rabbit ileal-loop test (RILT) was chosen for assaying enterotoxin in the first instance because it is potentially of greater biological relevance than tissue-culture cell assays. To our knowledge these well-characterised strains have not been examined in this way before.

\section{Materials and Methods}

\section{Bacterial strains}

S. typhimurium strains TML, W118, SL1027, LT7, M206 and Thax-1 were generously provided by Drs R. A. Giannella and J. W. Peterson. Strains TML, W118 and M206 had been shown to invade and induce fluid secretion in RILT (here designated ++ ). Strain SL1027 and LT7 were invasive, but failed to induce fluid secretion $(+-)$ and strain Thax-1 was non-invasive and did not induce fluid secretion (--) (Giannella et al., 1973). E. coli strain $\mathrm{H} 10407$ was used as a positive control for LT and ST production (Evans et al., 1974). E. coli strain O26: H1l was used as a positive control for ShiT production (Wade et al., 1979). All strains were stored at $-70^{\circ} \mathrm{C}$ in 1$\mathrm{ml}$ portions of equal volumes of glycerol and MuellerHinton-Broth cultures.

\section{Invasiveness and fluid secretion}

S. typhimurium strains were tested for invasiveness and induction of fluid secretion in RILT by the method of Giannella et al. (1973) with the following modifications. The bacteria were grown in Hartley Digest Broth, washed in sterile saline, and resuspended in Hartley Digest Broth. One-ml volumes of suspension (c. $5 \times 10^{8}$ viable bacteria/ $\mathrm{ml})$ were injected into ligated rabbit ileal loops constructed in $1 \cdot 5-2-\mathrm{kg}$ Dutch rabbits. Fluid secretion in RILT was recorded as fluid accumulated after $18 \mathrm{~h} \mathrm{in} \mathrm{ml} /$ $\mathrm{cm}$ of loop. Invasiveness was assessed by culturing heart blood and portions of liver and spleen for S. typhimurium in selenite enrichment broth at $37^{\circ} \mathrm{C}$. Overnight enrichment cultures were then streaked on to MacConkey's Agar. Colonies of $S$. typhimurium were identified by slide agglutination with monovalant anti-salmonella $\mathrm{O} 4$ antiserum.

\section{Enterotoxin production}

Stored S. typhimurium strains were thawed at room temperature and streaked on to MacConkey's Agar. After overnight incubation at $37^{\circ} \mathrm{C}$, ten colonies were picked and suspended in sterile saline $(\mathrm{NaCl} 9 \mathrm{~g} / \mathrm{L})$. This suspension $(0.1 \mathrm{ml})$ was used to inoculate $80 \mathrm{ml}$ of Casamino Acid Yeast Extract (CYE) broth (casamino acids, Oxoid, $10 \mathrm{~g} / \mathrm{L}$; yeast extract, LabM, $1.5 \mathrm{~g} / \mathrm{L}$; $\mathrm{MgSO}_{4} 0.1 \mathrm{~g} / \mathrm{L} ; \mathrm{MnCl}_{2} 0.05 \mathrm{~g} / \mathrm{L} ; p \mathrm{H} 8.0$ ). CYE-broth cultures in $250-\mathrm{ml}$ conical flasks were incubated at $37^{\circ} \mathrm{C}$ overnight with shaking $(140 \mathrm{rpm})$. Five-ml volumes of overnight culture were used to inoculate each of eleven 80-ml volumes of CYE broth which were incubated with shaking for $6 \mathrm{~h}$ at $37^{\circ} \mathrm{C}$. A sample of each broth culture was taken for estimation of total bacterial count in a Thoma counting chamber, and the organisms harvested by centrifugation at $15000 \mathrm{~g}$ for $25 \mathrm{~min}$ at $4^{\circ} \mathrm{C}$. Culture supernates were filter-sterilized $(0 \cdot 2-\mu \mathrm{m}$ filters) and streaked on to MacConkey's Agar to check for sterility before assaying in RILT. Pellets were resuspended in 80 $\mathrm{ml}$ of "toxin release buffer" (TRB; polymyxin B sulphate, Sigma, $6 \mathrm{~g} / \mathrm{L}$, dissolved in $\mathrm{NaCl} 9 \mathrm{~g} / \mathrm{L}$ in $0.15 \mathrm{~m} \mathrm{Tris} / \mathrm{HCl}$, Sigma; $p \mathrm{H}$ 6.6). Polymyxin-B extraction was used because LT is released from the periplasmic space of enterotoxigenic $E$. coli by this treatment (Evans et al., 1974). TRB suspensions were incubated at $37^{\circ} \mathrm{C}$ for $7 \mathrm{~min}$ with manual agitation. The suspensions were then centrifuged at $15000 \mathrm{~g}$ for $25 \mathrm{~min}$ at $4^{\circ} \mathrm{C}$. The supernates were filtersterilised $(0 \cdot 2-\mu \mathrm{m}$ filters) and dialysed against dry polyethylene glycol (PEG, mol. wt. 4000) until the volume was reduced to $20 \mathrm{ml}$. The concentrated extract was then dialysed overnight at $4^{\circ} \mathrm{C}$ against PBSA $(\mathrm{NaCl} 8 \mathrm{~g} / \mathrm{L} ; \mathrm{KCl}$ $0.2 \mathrm{~g} / \mathrm{L} ; \mathrm{Na}_{2} \mathrm{HPO}_{4} 1.43 \mathrm{~g} / \mathrm{L} ; \mathrm{KH}_{2} \mathrm{PO}_{4} 0.2 \mathrm{~g} / \mathrm{L} ; p \mathrm{H} \mathrm{7.3)}$, filter sterilised $\left(0 \cdot 2-\mu \mathrm{m}\right.$ filters) and stored at $4{ }^{\circ} \mathrm{C}$.

Other media were also tested for optimal enterotoxin production with strain TML. CYE medium was rendered iron-free (CYE-Fe) by the method of O'Brien et al. (1982) with Chelex 100 (Bio-Rad). The aim of culturing in this medium was to enhance possible ShiT production (O'Brien et al., 1982). A modified CYE medium (MCYE) reported to enhance LT production was also tested (Ristaino et al., 1983) (casamino acids $20 \mathrm{~g} / \mathrm{L}$; yeast extract $6 \mathrm{~g} / \mathrm{L} ; \mathrm{NaCl} 2.5 \mathrm{~g} / \mathrm{L} ; \mathrm{K}_{2} \mathrm{HPO}_{4} 8.71 \mathrm{~g} / \mathrm{L}$; glucose 2.5 $\mathrm{g} / \mathrm{L}$; trace salt solution $1 \mathrm{ml} / \mathrm{L}$ containing $\mathrm{MgSO}_{4} 50 \mathrm{~g} / \mathrm{L}$, $\mathrm{MnCl}_{2} 5 \mathrm{~g} / \mathrm{L}, \mathrm{FeCl}_{3} 5 \mathrm{~g} / \mathrm{L}$ in $\mathrm{H}_{2} \mathrm{SO}_{4} 5 \mathrm{mmol} / \mathrm{L} ; p \mathrm{H} \mathrm{8.5)}$. Culture supernates and polymyxin-B extracts were prepared as for CYE preparations. Six- and 24-h cultures of strain TML in the three media (CYE, CYE-Fe and MCYE) were prepared. Sterileculture supernates and polymyxin-B extracts were tested for enterotoxic activity.

\section{Enterotoxin assays}

Supernates and polymyxin-B extracts were assayed for enterotoxic activity in the following test systems.

\section{$R I L T$}

Sterile 1-ml samples were assayed in closed $5-\mathrm{cm}$ ileal loops constructed according to the methods of Giannella et al. (1973) as modified by Sedlock and Deibel (1978). Ileal loops were washed with $10 \mathrm{ml}$ of intestinal wash solution ( $\mathrm{N}$-acetyl cysteine, Sigma, $5 \mathrm{~g} / \mathrm{L}$, dissolved in sodium citrate $7.04 \mathrm{~g} / \mathrm{L}$ in PBSA). Purified CT $(1.5 \mu \mathrm{g}$ in $1.0 \mathrm{ml})$ or sterile culture supernate of $E$. coli $\mathrm{H} 10407(1.0$ $\mathrm{ml}$ from an $18 \mathrm{~h}$ shake culture in MCYE medium) were used as positive controls and $1.0 \mathrm{ml}$ TRB as the negative control. Results were recorded only in rabbits in which the positive control loops contained $\geqslant 0.5 \mathrm{ml}$ of fluid $/ \mathrm{cm}$ and negative control loops were empty. Full-thickness biopsies were fixed overnight in formol saline (formaldehyde $10 \%$ in saline), embedded in wax, sectioned and stained with haematoxylin and eosin for histological examination. 


\section{Tissue culture assays}

Samples were assayed for CT-like activity in Chinese hamster ovary (CHO), Y1 adrenal and Vero cells (Donta et al., 1974; Guerrant et al., 1974; Speirs et al., 1977) and ShiT-like activity in Vero cells (Konowalchuk et al., 1977). Samples $(0 \cdot 1 \mathrm{ml})$ of culture supernates and polymyxin-B extracts of $S$. typhimurium strain TML (from $6 \mathrm{~h}$ and $24 \mathrm{~h}$ CYE, CYE-Fe and MCYE cultures) were assayed. Positive controls for CT-like activity included serial dilutions of purified CT (from $0.1 \mu \mathrm{m} / \mathrm{ml}$ ), $0.1 \mathrm{ml}$ of E. coli $\mathrm{H} 10407$ sterile culture supernate (18 h culture in MCYE medium) and for ShiT-like activity $0.1 \mathrm{ml}$ of sterile culture supernate from $E$. coli $\mathrm{O} 26: \mathrm{H} 11$ grown for $24 \mathrm{~h}$ in Trypticase Soy Broth (Konowalchuk et al., 1977).

\section{Infant mouse assay}

Samples $(0 \cdot 1 \mathrm{ml})$ of sterile supernates or polymyxin-B extracts of $S$. typhimurium TML cultures $(6 \mathrm{~h}$; CYE medium) were assayed for ST-like activity (Dean et al., 1972). Positive control for ST was E. coli H10407 sterile culture supernate (18 h culture in MCYE medium). Intestinal weight/carcass weight ratios of $\geqslant 0.09$ were considered positive.

\section{Results}

\section{Biotyping of strains}

Invasiveness and induction of fluid secretion by the six strains are shown in table I.

\section{$R I L T$}

The results of testing culture supernates and polymyxin-B extracts for enterotoxic activity in RILT are shown in tables II-IV. Histological appearances (not shown) of ileal mucosa exposed to $S$. typhimurium enterotoxin preparations were

Table I. Invasiveness of and fluid secretion induced by strains of S. typhimurium in RILT

\begin{tabular}{lccccc}
\hline & & & \multicolumn{3}{c}{$\begin{array}{c}\text { Number of positive } \\
\text { cultures from* }\end{array}$} \\
\cline { 5 - 6 } Strain & $\begin{array}{c}\text { Number of } \\
\text { rabbits }\end{array}$ & $\begin{array}{c}\text { Fluid secretion } \\
(\mathrm{ml} / \mathrm{cm})\end{array}$ & blood & liver & spleen \\
\cline { 5 - 7 } TML & 3 & $0 \cdot 5,2 \cdot 5,3 \cdot 4$ & 1 & 3 & 2 \\
W118 & 3 & $0 \cdot 8,1 \cdot 0,1 \cdot 5$ & 0 & 3 & 3 \\
SL1027 & 3 & $0 \cdot 0,0 \cdot 2,0 \cdot 2$ & 0 & 3 & 3 \\
LT7 & 3 & $0 \cdot 0,0 \cdot 0,0 \cdot 5$ & 0 & 3 & 2 \\
M206 & 3 & $0 \cdot 0,0 \cdot 0,0 \cdot 5$ & 0 & 2 & 0 \\
Thax-1 & 3 & $0 \cdot 0,0 \cdot 0,0 \cdot 0$ & 0 & 0 & 0 \\
\hline
\end{tabular}

* One culture was taken from each named site from each rabbit.
Table II. Effect of culture medium and incubation time on the activity of polymyxin-B extracts of $S$. typhimurium TML in RILT

\begin{tabular}{lcccc}
\hline & $\begin{array}{c}\text { Incubation } \\
\text { time } \\
\text { (h) }\end{array}$ & $\begin{array}{c}\text { Number of } \\
\text { extracts } \\
\text { positive/ } \\
\text { number } \\
\text { tested }\end{array}$ & $\begin{array}{c}\text { Number of } \\
\text { rabbits with } \\
\text { positive } \\
\text { loops/ } \\
\text { number } \\
\text { tested }\end{array}$ & $\begin{array}{c}\text { Number of } \\
\text { loops } \\
\text { positive/ } \\
\text { number } \\
\text { used }\end{array}$ \\
\hline CYE & 6 & $11 / 11$ & $12 / 14$ & $30 / 36$ \\
CYE & 24 & $0 / 2$ & $0 / 2$ & $0 / 2$ \\
CYE-Fe & 6 & $2 / 3$ & $3 / 4$ & $4 / 5$ \\
CYE-Fe & 24 & $0 / 1$ & $0 / 1$ & $0 / 1$ \\
MCYE & 6 & $0 / 1$ & $0 / 1$ & $0 / 1$ \\
\hline
\end{tabular}

* See Methods.

Table III. Effect of culture medium and incubation time on activity of concentrated culture supernates of $S$. typhimurium TML in RILT

\begin{tabular}{lcccc}
\hline & $\begin{array}{c}\text { Incubation } \\
\text { time } \\
\text { (h) }\end{array}$ & $\begin{array}{c}\text { Number of } \\
\text { supernates } \\
\text { positive/ } \\
\text { number } \\
\text { tested }\end{array}$ & $\begin{array}{c}\text { Number of } \\
\text { rabbits with } \\
\text { positive loops/ } \\
\text { number } \\
\text { tested }\end{array}$ & $\begin{array}{c}\text { Number of } \\
\text { loops } \\
\text { positive/ } \\
\text { number } \\
\text { used }\end{array}$ \\
\hline CYE & 6 & $0 / 3$ & $0 / 3$ & $0 / 3$ \\
CYE & 24 & $1 / 3$ & $1 / 4$ & $1 / 6$ \\
CYE-Fe & 6 & $0 / 2$ & $0 / 2$ & $0 / 2$ \\
CYE-Fe & 24 & $0 / 3$ & $0 / 3$ & $0 / 3$ \\
MCYE & 6 & $0 / 1$ & $0 / 1$ & $0 / 1$ \\
MCYE & 24 & $1 / 2$ & $1 / 2$ & $1 / 2$ \\
\hline
\end{tabular}

* See Methods.

Table IV. Activity of polymyxin-B extracts of various $S$. typhimurium biotypes in RILT

\begin{tabular}{|c|c|c|c|c|}
\hline Strain & Biotype* & $\begin{array}{c}\text { Number of } \\
\text { extracts } \\
\text { positive/ } \\
\text { number } \\
\text { tested }\end{array}$ & $\begin{array}{l}\text { Number of } \\
\text { rabbits with } \\
\text { positive loops/ } \\
\text { number } \\
\text { tested }\end{array}$ & $\begin{array}{c}\text { Number of } \\
\text { loops } \\
\text { positive/ } \\
\text { number } \\
\text { used }\end{array}$ \\
\hline TML & ++ & $11 / 11$ & $12 / 14$ & $30 / 36$ \\
\hline W118/2 & ++ & $4 / 6$ & $8 / 13$ & $8 / 18$ \\
\hline LT7 & +- & $2 / 3$ & $3 / 5$ & $5 / 12$ \\
\hline SL1027C & +- & $3 / 3$ & $3 / 5$ & $5 / 10$ \\
\hline M206 & +- & $4 / 6$ & $3 / 8$ & $9 / 19$ \\
\hline Thax-1 & -- & $1 / 3$ & $1 / 6$ & $1 / 10$ \\
\hline
\end{tabular}

* See Methods. 
indistinguishable from those of positive control mucosa exposed to cholera toxin and sterile culture filtrates of $E$. coli $\mathrm{H} 10407$; they were essentially normal.

\section{Tissue culture assays}

All culture supernates and polymyxin-B extracts of $S$. typhimurium TML failed to induce morphological changes in $\mathrm{CHO}, \mathrm{Y} 1$ adrenal and Vero cells or cytotoxic changes in Vero cells. Characteristic CT- and LT-induced morphological changes were observed in CT and E. coli $\mathrm{H} 10407$ positive control wells in $\mathrm{CHO}, \mathrm{Y} 1$ adrenal and Vero assays; the effects were neutralised by anti-CT antibody. Cytotoxicity characteristic of ShiT-like activity occurred in Vero cells exposed to $E$. coli $\mathrm{O} 26$ : $\mathrm{H} 11$ supernate. Titres for CT and E. coli $\mathrm{H} 10407$ supernates were 512 and 128 respectively in $\mathrm{CHO}, \mathrm{Yl}$ and Vero cell assays, and 32 for $E$. coli $\mathrm{O} 26: \mathrm{H} 11$ supernate in the Vero cell assay.

\section{Infant mouse assays}

Six-hour culture supernates and polymyxin-B extracts of $S$. typhimurium TML gave negative results in tests for ST-like activity. Intestinal weight/ carcass weight ratios were $<0.07 ;$ E. coli $\mathrm{H} 10407$ supernate produced a ratio of $0 \cdot 16$.

\section{Discussion}

In this paper we report findings on previously well-characterised strains of $S$. typhimurium of known virulence in primates and rabbits. To our knowledge this is the first study in which enterotoxin production in vitro by these strains, assayed by RILT, has been compared with the ability of the whole organisms to induce fluid secretion in rabbit ileal loops.

Giannella et al. (1973) established that the rabbit ileal loop was a reasonable model of ileal infection in monkeys (and possibly, by extension, in man). Though invasiveness does not itself cause diarrhoea, as measured by causing fluid secretion in RILT, it appears to be a prerequisite. As shown in table I, the properties of these strains (with the possible exception of M206-see below) have not changed with prolonged storage. Strains TML and W1 18 consistently were invasive and induced fluid secretion $(++)$, strains SL1027 and LT7 were invasive and did not induce fluid secretion $(+-)$. Strains Thax-1 was non-invasive and did not induce fluid secretion (- $)$. In our hands, strain M206 failed to induce fluid secretion in two of three rabbit ileal loops and gave a borderline positive result ( $0 \cdot 5$ $\mathrm{ml}$ of fluid $/ \mathrm{cm}$ ) in the third loop. This differs from the finding of Giannella et al. (1973) that strain M206 induced fluid secretion in RILT; they did however report that this strain was less virulent than strains TML or W118 because it failed to cause diarrhoea in monkeys. Thus our findings are consistent with their results in monkeys.

Sterile, concentrated supernates of $S$. typhimurium cultured for $6 \mathrm{~h}$ and $24 \mathrm{~h}$ in CYE, CYE-Fe and MCYE media gave, with few exceptions, negative results in RILT (table III), in contrast with supernates from $V$. cholerae (De, 1959) and LT-producing E. coli (this report and Pierce and Wallace, 1972) which gave positive results in RILT.

Enterotoxic activity was therefore sought in polymyxin-B extracts of strain TML grown for $6 \mathrm{~h}$ in CYE medium, and then in similar extracts from other strains. Extracts of strain TML were tested in 36 loops in 14 rabbits; 30 treated loops in 12 rabbits gave positive results. The occurrence of negative results with some loops and rabbits indicates the variability of RILT for enterotoxin assays (see tables II-IV). It is not clear whether such variability is because (i) the amount of enterotoxin is close to the threshold of detectability in RILT; or (ii) the test has inherent biological variation; or (iii) certain rabbits are immune to the secretory effects of the enterotoxin by virtue of previous exposure to $S$. typhimurium. It is abundantly clear, however, that many RILT assays are required before firm conclusions can be drawn about the enterotoxicity of $S$. typhimurium extracts in this most meaningful of the current range of available tests. Table II also indicates that enterotoxic activity in polymyxin-B extracts was consistently greater in 6-h than in 24-h cultures in CYE medium as was also the case for extracts of organisms from CYE-Fe. Although two of three polymyxin-B extracts from iron-free 6-h cultures were enterotoxic, the expected histological changes characteristic of the effect of ShiT in RILT with strain TML extracts (Keusch et al., 1972) were not observed. This means either that strain TML does not produce a ShiT-like toxin, or that it is made in quantities too small to be detected in this test.

Crude enterotoxin preparations from strain TML resembled CT in that positive rabbit ileal loops were filled with watery fluid, and secretion was induced without mucosal damage. Attempts were made to neutralise the effect in RILT with antiCT antitoxin. The results (unpublished) varied between batches and were not repeatable. For this reason we used cell tests for cytotonic and cytotoxic toxins (which are potentially more quantitative) to 
demonstrate neutralisation of the $S$. typhimurium toxin. However, the results from the standard tissue-culture cell assays with $\mathrm{CHO}, \mathrm{Y}-1$ adrenal and Vero cells, were uniformly negative for presence of a CT-like toxin in $S$. typhimurium TML supernates and polymyxin-B extracts. In each test $C T$ and LT controls were positive and neutralisable. Similarly the infant-mouse assay for $E$. coli ST was negative with $S$. typhimurium. The cell and infantmouse tests have been repeated with identical results in Dr B. Rowe's laboratory at the Central Public Health Laboratory, Colindale with the same $S$. typhimurium supernates and extracts. From these data it must be concluded that salmonella enterotoxin does not behave consistently like CT in a range of standard tests.

The best yields of enterotoxin from strain TML were obtained by growing the organism in CYE medium for $6 \mathrm{~h}$ followed by polymyxin-B extraction. All six strains were examined in the same way (table IV). Although inter-loop and inter-rabbit variation again occurred, all strains, with the poss-

\section{REFERENCES}

De S N 1959 Enterotoxicity of bacteria-free culture-filtrate of Vibrio cholerae. Nature 18:1533-1534.

Dean A G, Ching Y-C, Williams R G, Harden L B 1972 Test for Escherichia coli enterotoxin using infant mice: application in a study of diarrhea in children in Honolulu. Journal of Infectious Diseases 125:407-411.

Donta S T, Moon H W, Whipp S C 1974 Detection of heat-labile Escherichia coli enterotoxin with the use of adrenal cells in tissue culture. Science 183:334-336.

Evans D J, Evans D G, Gorbach S L 1974 Polymyxin B-induced release of low-molecular-weight, heat-labile enterotoxin from Escherichia coli. Infection and Immunity 10:1010-1017.

Finkelstein R A, Marchlewicz B A, McDonald R J, BoesmanFinkelstein M 1983 Isolation and characterization of a cholera-related enterotoxin from Salmonella typhimurium. FEMS Microbiology Letters 17:239-241.

Giannella R A, Formal S B, Dammin GJ, Collins H 1973 Pathogenesis of salmonellosis. Studies of fluid secretion, mucosal invasion and morphological reaction in the rabbit ileum. Journal of Clinical Investigation 52:441-453.

Guerrant R L, Brunton L L, Schnaitman T C, Rebhun L I, Gilman A G 1974 Cyclic adenosine monophosphate and alteration of Chinese hamster ovary cell morphology: a rapid, sensitive in vitro assay for the enterotoxins of Vibrio cholerae and Escherichia coli. Infection and Immunity 10:320-327.

Jiwa SFH 1981 Probing for enterotoxigenicity among the Salmonellae: an evaluation of biological assays. Journal of Clinical Microbiology 14:463-472.

Jiwa S F H, Månsson I 1983 Hemagglutinating and hydrophobic surface properties of salmonellae producing enterotoxin neutralized by cholera anti-toxin. Veterinary Microbiology 8:443-458.

Keusch G T, Grady G F, Takeuchi A, Sprinz H 1972. The Pathogenesis of shigella diarrhoea. II. Enterotoxin-induced acute enteritis in the rabbit ileum. Journal of Infectious Diseases 126:92-95.

Koupal L R, Deibel R H 1975 Assay, characterization and ible exception of Thax-1, produced enterotoxic activity. It appears, therefore, that there is no correlation between production of enterotoxin in vitro and ability of whole organisms to induce fluid secretion in RILT. We conclude that the basis of differing virulence may be the ability to make and release toxin in vivo at the right time and to deliver it to the right tissue site. The potential importance of the release-as distinct from just synthesis-of toxin is supported by the data in tables I and II: supernates were infrequently positive whereas extracts were consistently positive in RILT. Similarly the degree of invasiveness may determine the amount of enterotoxin delivered to the mucosa. Other virulence determinants (e.g., the ability to survive in the tissues of the host) may be important in determining the ability of the fully virulent $(++)$ strains to cause disease and are under investigation.

We gratefully acknowledge the financial support of the Wellcome Trust.

localization of an enterotoxin produced by salmonella. Infection and Immunity 11:14-22.

Kétyi I, Pácsa S, Emödy L, Vertényi A, Kocsis B, Kuch B 1979 Shigella dysenteriae 1-like cytoxic enterotoxins produced by Salmonella strains. Acta Microbiologica Academiae Scientarum Hungaricae 26:217-223.

Konowalchuk J, Speirs J I, Stavric S 1977 Vero response to a cytotoxin of Escherichia coli. Infection and Immunity 18:775-779.

Koo F C W, Peterson J W, Houston C W, Molina N C 1984 Pathogenesis of experimental salmonellosis: inhibition of protein synthesis by cytotoxin. Infection and Immunity 43:93-100.

O'Brien A D, LaVeck G D, Thompson M R, Formal S B 1982 Production of Shigella dysenteriae type 1-like cytotoxin by Escherichia coli. Journal of Infectious Disease 146:763-769.

Pierce N F, Wallace C K 1972 Stimulation of jejunal secretion by a crude Escherichia coli enterotoxin. Gastroenterology 63:439-448.

Ristaino P A, Levine M M, Young C R 1983 Improved GM1enzyme-linked immunosorbent assay for detection of Escherichia coli heat-labile enterotoxin. Journal of Clinical Microbiology 18:808-815.

Sandefur P D, Peterson J W 1977 Neutralization of Salmonella toxin-induced elongation of Chinese hamster ovary cells by cholera antitoxin. Infection and Immunity 15:988-992.

Sedlock D M, Deibel R H 1978 Detection of Salmonella enterotoxin using rabbit ileal loops. Canadian Journal of Microbiology 24:268-273.

Speirs J I, Stavric S, Konowalchuk J 1977 Assay of Escherichia coli heat-labile enterotoxin with Vero cells. Infection and Immunity 16:617-622.

Stephen J, Wallis T S, Starkey W G, Candy D C A, Osbourne M P, Haddon S. 1985 Salmonellosis: in retrospect and prospect. In: Microbial toxins and diarrhoeal disease, Ciba Foundation Symposium No. 112. Pitman Medical, Tunbridge Wells, pp 175-192.

Wade W G, Thom B T, Evans N 1979 Cytotoxic enteropathogenic Escherichia coli. Lancet 2:1235-1236. 